\title{
Academic Diary: Or Why Higher Education Still Matters. Written by Les Back. New Cross, London: Goldsmith Press, 2016, pp. xiii + 258. ISBN 978-1-906- 89758-1.
}

\section{Reviewed by: Ahmad Faizuddin ${ }^{1}$}

In this age of free access to information one wonders if university education still matters today. In his book entitled Academic Diary: Or Why Higher Education Still Matters, Les Back, a Professor of Sociology at Goldsmiths, University of London, summarized three decades of his academic career. $\mathrm{He}$ pointed out daily aspects of campus life that have reshaped the process of education, presenting the journey of university life in a smart and humorous way. His diary not only examined the scholarly argument about the importance of higher education, but also criticized the impact of its commercialization.

As a reader, I found the first part of title-Academic Diary, somehow turning off. I thought this must be another boring story of a former student who becomes a lecturer at his alma mater. The second part of title, however, - Or Why Higher Education Still Matters, suggests a different turn. I felt that the author wants to show how the philosophy of modern higher education has changed dramatically and significantly.

The main sections of the book are divided according to the three different university terms, i.e. Autumn, Spring and Summer. As the author

\footnotetext{
${ }^{1}$ Department of Social Foundations and Educational Leadership, International Islamic University Malaysia (IIUM). Email: akhi.faizuddin@ gmail.com
} 
describes in the introduction part of the book, "It isn't a specific year but rather the accumulation of thirty years of reflection on the university and scholarship as both student and teacher, presented as a single year. Organized into three main seasons - autumn, spring and summer - the book tries to chronicle a sense of passing but repeated time in a life of learning" (p. 1).

While the organization of the academic year may be different in other parts of the world, people from other parts of the world can easily relate to it. Thus the book is organized in short chapters like a diary of events throughout the academic year. Following the diary structure, each entry is marked with a date and related to the time of the academic year. This gives the readers moments to reflect on their own exact same experiences and provides continuity of each academic year.

The author beautifully captured everyday campus life and the forces reshaping the university as higher education institution. These include things such as the habits of new students, the poor treatment to international students, the increasing university fees, the commercialization of education, the academic abuses of social media, the racism within the university, and the $\mathrm{PhD}$ supervision and viva. The following stories and the rest of the entries make the question of the relevance of higher education more influential.

First, the habits of learning have slightly changed among new students. Thus, the author was asked to give advice to an undergraduate student who was about to start her studies. In the entry "Letter to a New Student", he offers six valuable points new students should carefully consider about the prospects of university life. (1) Listen but don't be silent. Listening is part of the social furniture of the lecture hall. While it is important to be an active listener, one must at the same time be an active participant within lectures and seminars. So, students should speak out and ask questions when they don't understand. 'There is no such thing as a foolish question. It is the teacher's job to help you understand' (p. 19). 
(2) Care about your grades but don't make them your only goal. Today's education has become so bureaucratic that students are obsessed with targets and levels of achievement without reference to content of knowledge. To achieve the highest assessment levels, the content should be focused on first and second the grade. (3) Read and buy book. "There are essentially two kinds of book lovers. There are 'vandals' like myself who deface the printed page with marginalia, intelligent graffiti that either refute or applaud. Then there are 'preservationists' who jealously protect the virgin pages of their books from defilement. Being a book lover and buyer will help any student get the most out of their education regardless of which camp they end up in" (p. 21).

(4) Don't try and do it all the night before. Students must be academic writers in whatever fields they are interested in. They need to learn to be critical readers and this cannot be done in one night. (5) Don't be just a consumer. The university has been commercialized and turned the campuses into places of commerce. The commercialization of higher education doesn't promise a straightforward return to its paying consumers. Thus, students shouldn't be just passive consumers but have the right to demand the best returns from commodities offered. (6) Follow your interests. Student should explore their own interests by getting involved in university societies or the student union. These are experiences that cannot be found in course reading lists, but will be important for the rest of their lives.

Second, the treatment given to international students has gradually changed while university fees have drastically increased. In the entry "Students Not Suspects", the author criticized some aspects of academia like the poor treatment to international students and the increase in student fees that will impact their learning experiences. Universities are increasingly seeking new international markets to recruit undergraduates and postgraduates, but at the same time, international students are subjected to tight immigration control. They have to prove, for example, that they have enough money in their bank accounts to pay university fees and support themselves. The visa processes have also been made complicated to screen 
'legitimate students' only, but unfortunately also force them to return home afterwards. The author argues that students should be treated equally because they pay the same amount of tuition fees.

Third, education has become a commodity. In the entry "Teaching", Back described the continuous transformation of universities into businesses and commercial entities. He discussed some of the dilemmas university lecturers face and how they tackle them. For example, should a lecturer fail or not fail a student who turns in a poor piece of work? In the modern university, the lecturers are demanded by administrators to keep the pass rate high. From the perspective of students themselves, having paid exorbitant tuition fees, they believe that they should pass. Indeed, commodification of higher learning has changed student-learning experiences for better or worse. The university as higher education institution has coped with the Industrial Revolution. However, it seems to lose its way when it moves into a post-industrial society. We do hope that the ideal of scholarship traditions and excellent teaching will not have been forgotten.

Fourth, the advancement of social media has been used and abused for academic purposes. In the entry "Academic Uses and Abuses of Twitter", the author criticized the habit of sharing messages on Twitter in the digital age as a new medium for academic pride, "I started to notice Twitter being used only as a broadcast medium by some 'celebrity academics' who were just advertising themselves: 'something else written by me', 'a brilliant review of me', 'PhD scholarships that I will handling out', etc." (p. 109).

Academic vanity is like a symbolic image of Auguste Comte's mirror, the architect of positivism who coined the term 'sociology', in which a large mirror the same size as Comte's writing desk stands against a wall so that he could write a sentence and then pause to admire himself. But Twitter cannot be blamed for this academic vanity. Academic celebrity and the faculty should use it for academic purposes allowing others to follow 
scholarly hunches and tips, and bridging interaction among academic researchers, students, and other citizens to interact in the digital world. Twitter also has the power mechanism to reconnect with former students and colleagues. As the author put it, Twitter makes scholarship more sociable.

Fifth, racism has damaged academic freedom. The "Ivory Tower" depicted racism which is inevitable and universal. In higher education, has damaged the academic, civic freedoms, and the educational process itself. Black colleagues, for instance, are normally undermined and subjected to racism inside and outside the classroom. Back firmly stated that, "Racism in higher education can't be pushed under the carpet any longer; too much has been deposited there already and there are too many undulations along the faculty floor. If the sheer weight of whiteness that bears down on the academy is to be lifted, there needs to be an open and difficult acknowledgement of the damage that racism has done inside the education system. Then, and perhaps only then, will universities be ready to play a role in producing a post-imperial society that is at peace with itself' (p. 143).

Sixth, $\mathrm{PhD}$ supervision and the viva voce have become traumatic experiences. The entry "Supervision" provides thought-provoking aspects of $\mathrm{PhD}$ supervision and how it should be done. Although there are professional development courses related to this issue, students still feel confused. Supervision, as the author described it, should be "a kind of intellectual friendship that often extends far beyond the time it takes to write the thesis," but the fact is it is a kind of "intellectual interrogation that crushes rather than fosters confidence" (p. 160). On the other hand, "supervision is a place of deliberation and a time of thinking together, where potential answers are tossed around and tried out rather than transmitted from supervisor to student” (p. 161).

Hence, Back described the qualities of being a good supervisor based on students' points of views. First of all, a supervisor needs to be interested in the student's work. Intellectual excitement is important to keep the quality 
of scholarly tradition. Second, a supervisor needs to be patient to listen attentively, read carefully and make the student feel convenient. Good supervision encourages students to arrive at answers for themselves and does not provide everything for them. Third, a supervisor needs to criticize honestly but constructively. In this sense, what is required from a supervisor is to be a committed reader and support the process until the end. Fourth, a supervisor enables students to explore ideas in the mainframe of their interested research. Fifth, a supervisor should also keep in mind the future of the students and their scholarly career path.

Additionally, the author criticized the process of the viva voce which is often traumatic to students, and described the qualities an examiner should have. A basic structure of all varieties of $\mathrm{PhD}$ viva voce consists of "examiners read(ing) the thesis and form(ing) an independent judgment about it then ask(ing) the candidate questions in the context of 'live talk' which is the literal translation of the Latin phrase viva voce" (p. 201). Back argued that $\mathrm{PhD}$ viva is a kind of intellectual gambling. To satisfy the expectations of the examiners, students often worry unnecessarily and spend time preparing "how to describe in clear and concise terms where the idea for the project came from, how the idea was investigated, and what was found out and why it is interesting" (p. 203). The fact is that what is more crucial is to be clear about the idea presented, its ethical integrity, and what can be learned from the research. Regarding the examiner, the ideal one as proposed by the author is "someone who will read the work in its own terms, be fair and intellectually open-minded and at the same time searching and critical" (p. 207).

As the concluding remarks, the author provides an afterword describing how the diary came to be written in the first place. One important think to note, despite the vast amount of literature the author engaged with, Back does not provide footnotes in all of his entries in the 'diary'. However, he lists down all the resources and groups them under a number of themes such as 'Tips, Leads and Follow-Ups', 'Universities in Changing Times', 'Campus Fictions', 'Students, Learning and Teaching', 'On Writing and 
Writers', 'Intellectual Life and Its Purpose', 'Heroes and Heroines', and 'Music as a Hinterland'. These will give the readers a number of references for further readings.

Finally, this book is a must read for anyone, especially the students who are embarking on the academic journey, academics working in a contemporary university, and those considering embarking on a career in the academy. It is significant as it provides thought-provoking facets of academia and some challenges facing higher education today. The author has beautifully captured his journey as an academic staff and compared and contrasted this with his experiences when he was a college student. Although the descriptions are in the form of stories, the book indeed has a great realistic perspective on the changing nature of higher education. 